\title{
PERAN ORGANISASI MASSA PEREMPUAN DALAM PEMBANGUNAN PERDAMAIAN (Studi Kasus Muslimat NU Jawa Tengah)
}

\author{
Umma Farida \\ Institut Agama Islam Negeri (IAIN) Kudus \\ Email:ummafarida@stainkudus.ac.id
}

\begin{abstract}
ABSTRAK
Artikel ini bertujuan mengungkap peran organisasi massa (ormas) perempuan dalam mewujudkan dan membangun perdamaian yang sering kali terabaikan dari perhatian publik. Ini dikarenakan pada umumnya ormas perempuan hanyalah sebagai badan otonom dari organisasi induknya. Padahal gerakan, kiprah, dan perjuangan mereka sangatlah signifikan, termasuk dalam upaya mewujudkan kerukunan intern dan antar umat beragama. Pengumpulan data dilakukan dengan metode dokumentasi, wawancara, dan observasi, lalu dianalisis secara deskriptif-kritis. Hasil penelitian menunjukkan bahwa Pengurus Wilayah Muslimat NU Jawa Tengah merupakan salah satu ormas perempuan yang menaruh atensi terhadap pembangunan perdamaian di Jawa Tengah. Selama 2 tahun pertama masa khidmahnya (2016-2018), PW Muslimat NU Jawa Tengah telah melakukan upaye pembangunan perdamaian tersebut melalui model dialogue in communitydan dialogue of life yang dapat diklasifikasikan ke dalam dua bentuk, yaitu: melakukan capacity building di internal pengurus dan anggota PW Muslimat NU Jawa Tengah dengan mengedepankan sikap moderat dalam beragama, dan membangun harmonisasi intern dan antar umat beragama dengan bersinergi melakukan kesepakatan bersama lembaga pemerintah dan organisasi keagamaan lainnya dalam rangka menghindarkan klaim kebenaran dan mengembangkan toleransi.
\end{abstract}

Kata Kunci: Organisasi Massa Perempuan, Muslimat NU, 
Pembangunan Perdamaian

\begin{abstract}
This article aims to reveal the role of women's mass organizations in realizing and building peace that are often overlooked since in general they are only autonomous boards of their main organization. Data was collected by the method of documentation, interviews, and observations, and then analyzed descriptively-critically. The results of the study indicate that $P W$ Muslimat NU Central Java is one of the women's organizations that put attention on peace building in Central Java in the range of 2016-2018. PW Muslimat NU Central Java has made peace building efforts through a dialogue in community and dialogue of life model that can be classified into two forms, namely: capacity building in the internal management and members of the PW Muslimat NU Central Java by promoting moderate attitude in religion, and building internal and inter-religious harmonization by synergizing in agreement with government institutions and other religious organizations in order to avoid truth claims and develop tolerance.
\end{abstract}

Keywords: Women's Mass Organization, Muslimat NU, Peace Building

\title{
A. Pendahuluan
}

Islam memuliakan derajat kaum perempuan dari yang semula terhina menjadi makhluk yang bermartabat. Perempuan memiliki hak dan kewajiban yang sama dengan laki-laki dalam beramal saleh dan kelak juga sama-sama memperoleh hasil dari apa yang diupayakannya (QS. An-Nahl: 97).

Banyak organisasi perempuan yang memberikan atensi besar terhadap perdamaian dan harmonisasi umat beragama, seperti Muslimat Nahdlatul Ulama (NU), Fatayat, Aisyiyah, Nasyiatul Aisyiyah, Salimah, dan lainnya. Meskipun organisasi-organisasi perempuan tersebut merupakan sayap perempuan atau badan otonom dari organisasi induknya, namun gerakan, kiprah, dan perjuangan mereka tidak dapat dipandang sebelah mata. Akan tetapi peran ini sering kali menjadi terabaikan dan terlupakan. Akibatnya, perjuangan panjang yang telah diupayakan oleh organisasiorganisasi tersebut menjadi perjuangan 'gelap' yang tidak banyak diketahui publik. 
Artikel ini bertujuan untuk mengungkap peran dan perjuangan yang telah diupayakan Pimpinan Wilayah (PW) Muslimat NU Jawa Tengah dalam membangun perdamaian dan mewujudkan kerukunan umat beragama di Jawa Tengah, selama kurun waktu bulan Januari 2016 s.d Februari 2018. Pilihan terhadap Muslimat NU dikarenakan organisasi ini merupakan organisasi gerakan perempuan berbasis massa yang memperjuangkan keadilan, kemandirian, dan kesejahteraan kaum perempuan dengan kelompok sasaran gerakan perempuan akar rumput dan memusatkan kegiatannya pada bentuk-bentuk pengabdian yang bersifat religius-sosial. Pengumpulan data dilakukan dengan metode wawancara, observasi, dan dokumentasi melalui penelusuran literatur dan dokumen-dokumen yang terkait dengan kiprah PW Muslimat NU Jawa Tengah dalam pembangunan perdamaian dan perwujudan harmonisasi umat beragama. Selanjutnya dilakukan reduksi data dan dianalisis secara deskriptif-kritis dengan menggunakan pendekatan gender yang memusatkan perhatian pada ketidakadilan struktural dan sistem yang disebabkan oleh gender (Fakih, 1996: 71).

\section{B. Pembahasan}

\section{Perempuan dan Pembangunan Perdamaian}

Kata 'Islam' dengan seluruh derivasinya menunjuk pada arti keselamatan dan kedamaian. Ini menunjukkan bahwa agama yang dibawa Muhammad Saw. memang sungguh-sungguh berupaya membangun perdamaian dan keselamatan untuk umat manusia secara universal. Perdamaian dalam Islam terdeskripsikan melalui empat dimensi: Pertama, damai dalam konteks relasi manusia dengan Tuhan Sang Pencipta. Kedua, damai dengan diri sendiri (inner peace within self). Ketiga, damai dalam kehidupan, yakni manusia hidup dalam masyarakat yang bebas dari diskriminasi dan peperangan, serta diwujudkannya prinsip keadilan sosial dalam kehidupan sehari-hari. Keempat, damai dengan alam semesta dimana sumber daya dimanfaatkan bukan hanya untuk kebutuhan manusia saat ini tetapi juga dijaga dan dipelihara untuk kebutuhan generasi mendatang (Swara Rahima, 2011: 31).

Perdamaian menurut Johan Galtung dalam Imam Taufiq (2016: 3337 \& 42) didefinisikan sebagai segala prakarsa dan upaya kreatif manusia 
untuk mengatasi dan menghilangkan segala bentuk kekerasan, baik langsung maupun tidak langsung, struktural, kultural, maupun personal di masyarakat, melalui pemenuhan empat jenis kebutuhan dan hak-hak dasar dalam hidup, yaitu kesejahteraan (well-being),kebebasan (freedom), keamanan (security), dan identitas (identity). Oleh karena itu, kelangkaan atau tidak terpenuhinya keempat kebutuhan dasar itu akan menyebabkan manusia terjebak dalam berbagai jenis kekerasan, mulai dari kemiskinan, represi, kerusakan, hingga alienasi budaya. Selanjutnya, perdamaian ini dapat diklasifikasikan menjadi perdamaian negatif dan perdamaian positif.

Perdamaian negatif memfokuskan pada tidak adanya kekerasan secara langsung, seperti perang, pertikaian, perselisihan, dan sebagainya, sehingga pembangunan perdamaiannya lebih tepat dilakukan melalui jalur negosiasi atau mediasi daripada pendekatan fisik. Sedangkan perdamaian positif difokuskan pada pemenuhan rasa aman dan keadilan ekonomi dari sistem yang berlaku sampai terhapusnya diskriminasi agama, etnis, ras, dan struktur sosial. Atau dengan kata lain, perdamaian positif adalah sebuah kondisi yang dipenuhi oleh keadilan sosial (sosial justice). Oleh karena itu, perdamaian positif lebih bersifat jangka panjang dan bukan hanya sekedar ketiadaan perang. Adapun upaya pembangunan perdamaian positif ini dilandaskan pada pemahaman dasar dari kondisi-kondisi sosial dengan cara menghapus kekerasan struktural yang melampaui kekerasan fisik secara langsung. Selain itu, pembangunan perdamaian dituntut untuk bisa menjawab tantangan ganda, yaitu menghilangkan akar-akar penyebab pertikaian seraya memperbaiki hubungan yang porak-poranda antar pihak yang dalam waktu lama terjerumus dalam pertikaian.

Pembangunan perdamaian (peace building) berbeda dengan pemeliharaan perdamaian (peace keeping). Pembangunan perdamaian lebih dari sekedar kerja rekonstruksi dan rekonsiliasi pasca-konflik. Sedangkan pemeliharaan perdamaian biasanya terhenti ketika penghentian konflik senjata selesai atau penandatanganan sebuah perjanjian damai tanpa memikirkan upaya-upaya pembangunan perdamaian yang bersandarkan pada kemaslahatan manusia (Arivia, 2007: 25). Pembangunan perdamaian tidak bertujuan semata-mata menghapuskan kekerasan, melainkan juga 
menghilangkan potensi-potensi yang dapat memicu konflik di masa yang akan datang. Oleh karenanya, pembangunan perdamaian menuntut sebuah transformasi nilai-nilai masyarakat secara keseluruhan yang menjamin adanya kondisi perdamaian dan keadilan, serta tegaknya martabat manusia. Untuk mencapainya perlu ditumbuhkan aspek-aspek pembangunan perdamaian secara lebih luas seperti mengembangkan sikap saling menghargai, menerima perbedaan dan mendorong perubahan arah yang lebih positif dalam bidang sosial, politik, ekonomi, dan lainnya (Khariroh, 2011:8).

Prinsip kunci membangun perdamaian adalah keadilan. Keadilan menuntut hubungan yang seimbang antara dua pihak yang sama, sementara ketidakadilan akan menyebabkan ketidakseimbangan antara kedua pihak yang berbeda. Merujuk pada pendapat Hassan Hanafi (2002: 62), 'perang yang tak tampak' semisal kemiskinan, kesenjangan ekonomi, kelaparan, penyakit, pengangguran, diskriminasi, eksploitasi dan tekanan, merupakan faktor pengacau perdamaian yang kadarnya tidak berbeda dengan 'perang yang tampak' semisal agresi dan invasi. Oleh karenanya dalam konteks Indonesia, khususnya Jawa Tengah, membangun perdamaian atas perang yang tak tampak ini sama pentingnya dengan membangun perdamaian atas perang yang tampak.

Peran perempuan dalam mewujudkan dan membangun perdamaian tampak sering terabaikan. Ini disebabkan masyarakat masih sering menganggap perempuan sebagai makhluk domestik dan subordinat sedangkan laki-laki dipandang sebagai makhluk publik-politik yang superior. Realitas sosial, politik, ekonomi, dan budaya masih belum sepenuhnya memberikan ruang kepada kaum perempuan untuk berpartisipasi aktif dan formal dalam usaha-usaha membangun perdamaian, meskipun fakta telah mencatat peran penting mereka. Menurut Husein Muhammad (2011: 2627), dalam banyak peristiwa perang atau konflik sosial, kaum perempuan menjalankan peran dan berbagai aktifitas sosial, antara lain menjadi tenaga sukarela dalam aktifitas-aktifitas kemanusiaan, membantu penyaluran bahan pangan, obat-obatan dan kebutuhan pokok lainnya kepada masyarakat yang membutuhkan. Tidak jarang perempuan juga ikut dalam pertempuran dan menjadi kombatan untuk melindungi keluarga dan masyarakat dari serangan 
'musuh'. Bahkan, mereka juga aktif melakukan kegiatan advokasi bagi upaya perdamaian, dengan cara melakukan interaksi dan berkomunikasi dengan masyarakat yang tengah terlibat dalam konflik/perang. Selanjutnya kondisi seperti ini menginspirasi suami atau para pihak yang berkonflik untuk melakukan upaya-upaya rekonsiliasi dan perdamaian abadi.

Di luar kondisi konflik dan peperangan, perempuan sebagai aktor perdamaian berani melakukan sesuatu yang dapat memutus mata rantai kebencian dan balas dendam.

\section{Profil Muslimat NU Jawa Tengah}

Muslimat Nahdlatul Ulama (NU) berdiri pada saat Muktamar NU ke XVI di Purwokerto Jawa Tengah pada 29 Maret 1946 (Sri Mulyati dkk., 2016: 9) dan kepemimpinan wilayahnya tersebar ke seluruh propinsi di Indonesia. Adapun untuk Muslimat NU Jawa Tengah membina 38Cabang tingkat Kabupaten/Kota se-Jawa Tengah, 415 Pimpinan Anak Cabang tingkat Kecamatan, dan 5.227 Pimpinan Ranting tingkat Kelurahan. Dalam usianya yang ke-72 tahun, Muslimat NU Jawa Tengah telah memberikan lima layanan pengabdian yang meliputi: layanan sosial, layanan kesehatan, layanan di bidang dakwah, layanan di bidang pendidikan dan layanan ekonomi. Kelima layanan ini diwujudkan dalam bentuk aksi melalui pengelolaan 33 Panti Asuhan "Darul Hadlonah”, 25 Rumah Sakit/Rumah Bersalin atau Poliklinik, 1 Panti Lansia, 1 Panti Wredha, dan 3 TempatPenitipanAnak/Day care. Selain itu, PW Muslimat NU Jawa Tengah membina 6.847 TK/RA/KB/TPQ dan Madrasah Diniyah, 21.897 Majlis Ta’lim yang tersebar diseluruh penjuru Jawa Tengah, mengelola 37 Koperasi Primer "An-Nisa" dan 1 Puskop "AnNisa” Jawa Tengah, serta 17 Kelompok Bimbingan Ibadah Haji dan Umroh (KBIH) Muslimat NU. Keseluruhan layanan ini dikelola dan ditangani oleh Yayasan yang didirikan Muslimat NU, yakni Yayasan Pendidikan Muslimat NU (YPM), Yayasan Haji Muslimat NU (YHM) dan Yayasan Kesejahteraan Muslimat NU (YKM) (Database MNU Jateng, Desember, 2017).

Optimalisasi layanan Muslimat NU di masyarakat bertujuan untuk merealisasikan visi Muslimat NU, yaitu terwujudnya masyarakat sejahtera yang dijiwai ajaran Ahlussunnah wa al-Jama’ah dalam Negara Kesatuan 
Republik Indonesia yang berkemakmuran dan berkeadilan yang diridlai Allah Swt. Dari visi ini, tampak bahwa masyarakat sejahtera menjadi kata kunci dalam setiap kegiatan dari program yang dijalankan Muslimat NU baik kegiatan layanan pendidikan, sosial, agama, dan ekonomi. Dalam pada itu, kesejahteraan tidak akan pernah bisa diwujudkan kecuali dalam situasi damai dan harmonis.

Sebagai organisasi massa perempuan, pengembangan Muslimat NU didasarkan pada 6 (enam) asas, yaitu: Pertama, asas kekeluargaan. Muslimat NU menekankan pada semangat kekeluargaan di antara anggotanya yang dibangun melalui rasa saling asah, asih, dan asuh. Asas kekeluargaan ini menjadi dasar seluruh kegiatan guna mencapai tujuan organisasi. Kedua, asas keseimbangan, dalam hal ini Muslimat NU mengedepankan keseimbangan antara kepentingan dunia dan akhirat, spiritual dan material, jasmani dan rohani masyarakat. Ketiga, asas kemandirian, yakni Muslimat NU tidak memiliki ketergantungan dengan pihak lain, yakin akan kemampuan dan potensi diri dalam setiap perjuangan di masyarakat. Seandainya upaya kerjasama dengan berbagai pihak dilakukan, hal tersebut tidak mengurangi arti kemandirian Muslimat NU dalam menegakkan prinsip dan nilai yang mendasari perjuangannya di masyarakat. Keempat, asas kepeloporan. Sebagai organisasi yang memiliki anggota sangat banyak, \pm 3 (tiga) juta perempuan Jawa Tengah, pengurus dan anggota Muslimat NU diharapkan bisa menjadi pelopor dalam perjuangan peningkatan kualitas hidup perempuan dan anak. Kelima, asas manfaat, yakni seluruh upaya yang dilakukan memberi manfaat dan dapat dimanfaatkan sebesar-besarnya bagi umat manusia. Keenam, asas musyawarah, yang menjadi pijakan dalam melaksanakan berbagai kegiatan yang telah diprogramkan (Sri Mulyati dkk., 2016: 85-88).

Banyaknya animo masyarakat pedesaan yang bergabung menjadi anggota Muslimat NU tidak hanya dilandaskan pada motivasi agama saja, melainkan juga karena adanya kesadaran di antara masyarakat akan besarnya kompleksitas permasalahan hidup yang harus dihadapi secara efektif dan efisien. Dengan berorganisasi, masyarakat pedesaan memiliki harapan yang besar agar organisasi seperti Muslimat NU menjadi wadah yang tepat dalam mengikat sumber daya dan sumber manusia dari berbagai latar 
belakang keluarga, kekerabatan, suku sehingga organisasi seperti ini dapat mengikatkan anggota dengan pemimpinnya, menggabungkan kelompok, dan juga menggabungkan sarana produksi dan bahan mentah menjadi suatu hasil yang bernilai bagi kehidupan. Ini dikarenakan menurut Winarno (2003: 28), masyarakat desa pada dasarnya tertarik pada perubahan-perubahan dan memiliki kemampuan untuk memperbaiki kondisi-kondisi hidup mereka. Dengan demikian, ketika kaum perempuan pedesaan bergabung dengan Muslimat NU, banyak isu yang sebelumnya dilihat sebagai kepedulian pribadi dan domestik, seperti kesehatan ibu, pendidikan anak, pendapatan keluarga dan gizi menjadi isu publik dan politik. Anggota masyarakat yang dulunya sebelum bergabung dengan Muslimat NU memiliki anggapan bahwa masalah domestik adalah hal tabu dibicarakan di ruang publik seperti hak dan kewajiban suami istri, masalah kesehatan reproduksi, dan kekerasan dalam rumah tangga, namun setelah bergabung mereka menjadi pionir untuk menjelaskan permasalahan tersebut dengan perspektif Islam.

\section{Muslimat NU Jawa Tengah dan Peacebuilding}

Meskipun kini tidak ditemukan peperangan di Indonesia, bukan berarti pembangunan perdamaian tidak penting. Upaya pembangunan perdamaian tetap diperlukan, karena Indonesia, termasuk di Jawa Tengah, belum terbebas sepenuhnya dari sikap diskriminatif, kekerasan, dan intoleransi yang sering kali menjadi rintangan terwujudnya perdamaian. Terlebih sentimen agama mudah dibawa untuk melipatgandakan dukungan di dalam situasi konflik komunal. Apalagi di era posmodernisme, agama sebagai kenyataan sosial di masyarakat tidaklah hadir sebagai entitas tunggal, melainkan dalam bentuk kelompok-kelompok sesuai aliran-aliran pemikiran keagamaan yang dianutnya. Masing-masing kelompok itu tampak menuntut representatif afektif yang setara tanpa dipandang dari segi mayoritas-minoritas dan mainstream atau bukan, sehingga memunculkan perbedaan lebih mudah daripada membangun kesepakatan (Nafi', 2017: 13).

Sejatinya kaum perempuan memiliki banyak peluang dan kesempatan untuk membangun perdamaian. Kaum perempuan dalam hal ini para ibu memiliki kesempatan besar untuk membentuk kepribadian generasi 
masa depan, membekali mereka dengan pendidikan dan karakter positif untuk memasuki kehidupan yang lebih luas dalam masyarakat. Bisa jadi terkadang anak-anak terkontaminasi benih-benih intoleransi dari lingkungan bermain atau mungkin juga lingkungan sekolahnya. Di sinilah para ibu memainkankan peran sebagai peace-agent dengan memberikan pemahaman keagamaan yang lebih toleran dan moderat kepada anak-anaknya, karena ibu memiliki kemampuan untuk menjadi sandaran jiwa dan membentuk ruang keluarga yang memungkinkan anak-anak tumbuh dan berkembang secara baik dan wajar. Dalam hal ini, keluhuran moral merupakan hal yang selalu dikedepankan para ibu dalam mendidik anak-anaknya, karena moral (akhlak) merupakan kondisi mental-spiritual yang mendorong manusia untuk berperilaku, sekaligus bentuk kesadaran yang muncul dalam setiap individu yang secara aplikatif mendorong manusia untuk berbuat sesuatu.

Untuk membangun perdamaian, setidaknya ada 6 (enam) tantangan yang dihadapi para ulama perempuan Muslimat NU Jawa Tengah, yaitu: Pertama, kekerasan terhadap perempuan di Indonesia, termasuk Jawa Tengah, yang sangat memprihatinkan. Legal Resource Center untuk Keadilan Jender dan Hak Asasi Manusia (LRC-KJHAM) mencatat ada 352 kasus kekerasan terhadap perempuan yang tersebar di 35 Kabupaten/ Kota se-Jawa Tengah. (Tribun Jateng, 7/12/2017 \& Detiknews, 2/2/2018). Kedua, pernikahan dini yang masih marak terjadi di Jawa Tengah membawa dampak negatif dari aspek kesehatan dan ekonomi, seperti: kematian ibu dan bayi, tuntutan ekonomi keluarga yang mengharuskan bekerja dengan posisi rendah dan dengan upah yang rendah pula. Koalisi Perempuan Indonesia (KPI) mencatat selama 2016 ada 30.128 perempuan di bawah umur di Jawa Tengah mengajukan dispensasi agar bisa melakukan pernikahan dan $10 \%$ di antaranya disebabkan hamil di luar nikah. Selebihnya karena ingin menikah muda (Semarang Pos, 21/11/2017). Ketiga, perceraian di Jawa Tengah yang masih tinggi. Selama enam bulan pertama tahun 2017 mencapai 1.626 kasus, dan mayoritas perceraian dengan prosentase tinggi terjadi di Cilacap akibat gugat cerai dari pihak istri dengan berbagai faktor yang mendasarinya seperti faktor ekonomi, kekerasan dalam rumah tangga, ketidakharmonisan dan pertengkaran (https://news.okezone.com, 21/7/2017). Keempat, faktor 
kemiskinan. Badan Pusat Statistik Jawa Tengah merilis pada bulan September 2017, angka kemiskinan di Jawa Tengah mencapai 4.20 juta orang (12.23 $\%)$, berkurang sebesar 253.23 ribu orang dibandingkan dengan kondisi Maret 2017 yang sejumlah 4.45 juta orang (13.01\%) (https://jateng.bps. go.id, 2/1/2018). Kelima, problem kesehatan, seperti meningkatnya jumlah penderita HIV/AIDS dimana Jawa Tengah per Juni 2016 terdapa 6902 kasus (https://tribunnews.com, 29/7/2016) dan penyakit menular seperti tuberkolosis. Keenam, berkembangnya kelompok dan paham keagamaan yang cenderung radikal yang bisa berdampak pada perpecahan bangsa.

Mengatasi keenam problem di atas, peran PW Muslimat NU Jawa Tengah dalam membangun perdamaian dapat dibedakan menjadi dua bentuk: Pertama, capacity building di lingkungan anggota dan pengurus PW Muslimat NU Jawa Tengah. Kedua, membanguns inergi dalam mewujudkan harmonisasi dan mengembangkan toleransi intern dan antar umat beragama.

\section{a. Capacity Building Di Lingkungan Anggota dan Pengurus}

Bentuk pertama berupa capacity building di lingkungan pengurus PW Muslimat NU Jawa Tengah, diselenggarakan paling sedikit 3 (tiga) bulan sekali saat pertemuan Rapat Pleno. Di antara upaya penanganan problem-problem yang merintangi pembangunan perdamaian sebagaimana tersebut di atas, PW Muslimat NU Jawa Tengah mengklasifikasikan tugas para pengurus ke dalam 9 (sembilan) bidang, yaitu: Bidang organisasi dan keanggotaan; bidang pendidikan; bidang sosial budaya dan lingkungan hidup; bidang kesehatan dan kependudukan; bidang dakwah dan pengembangan masyarakat; bidang ekonomi, koperasi dan agrobisnis; bidang tenaga kerja; bidang hukum dan advokasi; bidang penelitian, pengembangan komunikasi dan informasi. Kesembilan bidang ini saling bersinergi dan bahumembahu dalam mengatasi problem tersebut sesuai tugas pokok dan fungsi (tupoksi) masing-masing. Dalam rapat pleno ini pula dilakukan konsolidasi di antara pengurus, termasukpenyamaan persepsi untuk tetap menjaga kerukunan intern dan antar umat beragama, serta membangun perdamaian. 
Perdamaian dalam kehidupan keluarga adalah awal dari perdamaian dalam kehidupan sosial kemasyarakatan. Problem pernikahan dini dan tindakan kekerasan, khususnya terhadap perempuan dan anak yang menjadi rintangan pembangunan perdamaian, secara perlahan diantisipasi oleh PW Muslimat NU Jawa Tengah melalui pembinaan yang dilakukan Bidang Pendidikan dan Dakwah. Bidang pendidikan menjalankan misinya melalui lembaga pendidikan yang dikelolanya, sementara bidang dakwah melalui majlis ta'lim dan pengajian.

Maraknya majlis ta'lim dan pengajian yang dibina oleh PW Muslimat NU Jawa Tengah dan memiliki basis massa akar rumput yang banyak telah memperkuat posisi strategis Muslimat NU dalam memperkuat dakwah yang toleran, baik dalam bentuk dakwah bi al-lisan maupun bi al-hal, menebarkan ajaran Islam yang ramah, menanamkan nilai-nilai kerukunan umat beragama, membangun perdamaian, serta mendampingi dan memberdayakan masyarakat ke arah yang lebih baik. Bahkan, menyadari pentingnya peran perempuan pendakwah dalam membina kerukunan umat beragama, PW Muslimat NU menyelenggarakan pelatihan Muballighat selama tiga hari di Pondok Pesantren Zainuddin Maribaya Tegal, 4 s.d 6 November 2017. PW Muslimat NU Jawa Tengah juga melaksanakan dakwah melalui seni dan tulisan melalui pelatihan dan lomba pembacaan diba' se-Jawa Tengah pada 11 Maret 2017 dan Pelatihan Jurnalistik pada 21 Januari 2017. Bahkan, gerakan dakwah Muslimat NU juga menjangkau kelompok rentan, seperti memberikan siraman rohani dan semangat hidup kepada para narapidana perempuan. (Dokumen Laporan Kegiatan PWMNU, 2017: 7).

Disamping melalui bidang dakwah, membangun perdamaian juga diupayakan melalui pendidikan. Salah satunya melalui review kurikulum yang mengedepankan keramahan dan toleransi khususnya bagi anak-anak usia dini yang dilaksanakan pada 12-13 Juli 2017. Hal ini sejalan dengan pendapat Abdurrahman Azzam Pasha (1985: 192) dan Sidek Baba (2002: 107) bahwa membangun perdamaian bisa 
dilakukan melalui pendidikan dengan menyampaikan berbagai kisah inspiratif tentang toleransi dan perdamaian yang terjadi pada masa Nabi Saw baik dilakukan oleh Nabi sendiri ataupun yang diajarkannya kepada para sahabat. Menyadari bahwa keadilan merupakan salah satu pilar terwujudnya perdamaian dan mengantisipasi terjadinya pernikahan dini dan kekerasan dalam rumah tangga, PW Muslimat NU Jawa Tengah mengacu pada langkah yang ditempuh Pimpinan Pusat Muslimat NU dalam menanamkan nilai-nilai kesetaraan antara laki-laki dan perempuan untuk menumbuhkembangkan keharmonisan antara keduanya, yaitu dengan menukilkan kisah-kisah teladan dari al-Qur'an maupun hadis. Kisah teladan tersebut mengkisahkan bahwa perempuan juga memiliki kewajiban yang sama, berjuang bersama laki-laki dalam menjalankan perintah Allah Swt. di masyarakat(Mulyati, 2016: 73-74).

Budaya patriarkhis yang relatif kental di lingkungan masyarakat NU tidak terelakkan menjadi tantangan tersendiri bagi para ibu Nyai Muslimat NU dalam menanamkan nilai-nilai kesetaraan tersebut. Penulis melihat bahwa keberanian untuk tampil di ruang publik masih terus perlu digalakkan di kalangan para perempuan Muslimat NU, tidak lagi hanya sebagai konco wingking bagi pasangannya. Di sini, Muslimat NU dihadapkan pada 3 (tiga) tantangan: kemampuan, kemauan, dan kesempatan. Kemampuan sudah dimiliki oleh banyak para ulama perempuan di lingkungan Muslimat NU Jawa Tengah yang memiliki kompetensi keagamaan yang tidak kalah dibanding para ulama laki-laki. Adapun kemauan tetap dapat dibangkitkan dengan melihat kenyataan masih banyaknya ruang kosong dalam pola perilaku masyarakat yang membutuhkan sentuhan agama. Sedangkan kesempatan ini memerlukan banyak kesadaran tidak hanya dari para ulama perempuan Muslimat NU untuk bisa membagi urusan domestik keluarga dan urusan publik terkait pengabdian yang dilakukannya, tetapi juga perlu dukungan masyarakat umum untuk berbagi peran dengan kaum perempuan dalam menanamkan nilai-nilai religiusitas kepada umat.

Selain itu, PW Muslimat NU Jawa Tengah juga merintis layanan pengetahuan Pra-Nikah bagi calon pengantin. Melalui pelatihan Pra- 
Nikah diharapkan masing-masing pasangan mengetahui hak dan kewajibannya sehingga tumbuh kesalingan positif antar keduanya. Hubungan yang saling memahami, mengisi dan mensupport, bukan hubungan yang saling menyalahkan dan menghakimi yang berujung pada diskriminasi, kekerasan, dan perceraian (Wawancara dengan Ismawati, 8/10/2017).

Rintangan keempat dan kelima dari upaya pembangunan perdamaian-berupa pengentasan kemiskinan dan problem kesehatan-juga diatasi dengan melakukan berbagai pelatihan kewirausahaan membuat makanan ringan layak jual dan pelatihan peningkatan produktifitas kerja yang telah dilakukan PW Muslimat NU Jawa Tengah, serta mensosialisasikan pendirian E-Warung dan Toko Kita (Tokita) di 38 Kabupaten/Kota se-Jawa Tengah (Wawancara dengan Choiriyah, 23/2/2018), serta pemberian bantuan bagi masyarakat miskin dan korban bencana alam.

Terkait dengan penyelesaian problem kesehatan seperti semakin banyaknya penderita HIV/AIDS dan tuberkolosis di Jawa Tengah yang turut berkontribusi menumbuhkan gap pemisah persatuan dan kerukunan masyarakat, maka PW Muslimat NU Jawa Tengah menyelenggarakan Edutainment Program HIV/AIDS yang dimaksudkan untuk mewaspadai meningkatnya jumlah penderita HIV/AIDS sekaligus terapi terhadap korban dan penderita HIV/ AIDS selama kurun waktu 1 s.d 29 Maret 2017 dan 25-27 November 2017dengan mengambil fokus layanan pada tiga kabupaten yang menjadi poros perkembangan HIV/AIDS di Jawa Tengah yaitu Kab. Sragen, Kab. Karanganyar, dan Kab. Grobogan.Adapun penanggulangan tuberkolosis dilakukan selama kurun waktu tanggal 28 November s.d 16 Desember 2017 di 16 (enam belas) Kabupaten di Jawa Tengah yang rentan penyakit tuberkolosis tersebut, yaitu: Kab. Tegal; Kab. Wonogiri; Kab. Pati; Kab. Rembang; Kab. Batang; Kab. Temanggung; Kab. Sukoharjo; Kab. Magelang; Kab. Boyolali; Kab. Grobogan; Kab. Pemalang; Kab. Blora; Kab. Klaten; Kab. Pekalongan; Kab. Wonosobo; dan Kab. Brebes. (Wawancara dengan Masfufah, 23/2/2018). 


\section{b. Membangun Sinergi dalam Mengembangkan Toleransi Intern} dan Antar Umat Beragama.

Selain membangun capacity building di internal pengurus dan anggota, PW Muslimat NU Jawa Tengah menempuh upaya harmonisasi intern dan antar umat beragama dengan bersinergi melakukan kesepakatan bersama dengan lembaga pemerintah dan organisasi kegamaan lainnya, seperti: NU, Muhammadiyah, Nasyi'atul A'isyiyah, Fatayat, Aisyiyah, Majelis Ulama Indonesia, Kepolisian Daerah dan lainnya untuk mengembangkan sikap saling menghormati dan menghargai pendapat dan keyakinan masing-masing dan menghindarkan klaim kebenaran (truth claim) bahwa hanya pendapat kelompoknyalah yang benar, sementara keyakinan kelompok lainnya adalah salah. Fakta bahwa 2 (dua) orang pelaku bom teror di Jalan Thamrin Jakarta yang diamankan Densus 88 pada 2/2/2018 adalah masyarakat Temanggung dan Banyumas Jawa Tengah, dan press-release yang disampaikan Direktur Reserse dan Kriminal Umum Kepolisian Daerah (POLDA) Jateng, Hery Santoso, bahwa 13 (tiga belas) orang teroris dari Jawa Tengah (sembilan orang di antaranya warga Soloraya) telah ditangkap sepanjang tahun 2017 (Semarang Pos, 1/1/2018), turut menjadi tamparan sekaligus cambuk bagi PW Muslimat NU Jawa Tengah untuk membendung sikap radikal dan membangun perdamaian. KarenabagiMuslimat NU, aksiterorisme adalah sebuah kejahatan kemanusiaan yang tidak berkaitan dengan ajaran agama. Aksi anarkhis dalam teror bom bukanlah membela Islam, melainkan justru telah menodai Islam dan merusak tatanan berbangsa dan bernegara, menimbulkan korban jiwa, luka-luka, fasilitas publik rusak, dan menimbulkan adu domba dan mengganggu tatanan keamanan masyarakat Indonesia (Rekomendasi Kongres XV Muslimat NU, 2006: 70)

Sikap tegas PW Muslimat NU Jawa Tengah terhadap aksi teror dinyatakan oleh Ismawati (24/5/2017),

"Sekarang umat Islam Indonesia termasuk di Jawa Tengah, sedang dikepung oleh gerakan Islam Transnasional. Beberapa waktu lalu kita dikagetkan dengan munculnya ISIS (Islamic State of Iraq and Syria), 
yang turut menumbuh kembangkan radikalisme dan terorisme di Indonesia, baik sekedar ikut-ikutan atau karena memang sepaham dengan misi dan tujuan gerakan tersebut. Para pengurus PW Muslimat NU seharusnya bisa memberikan pemahaman dan benteng pendidikan keagamaan, tidak hanya kepada putra-putrinya, tetapi juga kepada masyarakat sekitarnya, agar terwujud keharmonisan hidup intern ataupun antar umat beragama."

Kontribusi nyata PW Muslimat NU Jawa Tengah dalam membangun perdamaian dan kesepahaman intern dan antar umat beragama di antaranya ditunjukkan dengan mengirimkan delegasi dalam kepengurusan Forum Komunikasi Penanggulangan Terorisme (FKPT) Jawa Tengah dan terlibat aktif dalam berbagai kegiatan yang mengarah pada upaya-upaya membendung terorisme dan radikalisme serta pembangunan perdamaian bangsa, baik yang diselenggarakan institusi pemerintah maupun lembaga swasta lainnya, sebagaimana dilakukan Muthi'ah Chudlori (delegasi PW Muslimat NU dalam FKPT Jawa Tengah) yang turut memberikan pencerahan dan penguatan kapasitas lembaga pendidikan keagamaan dalam menangkal paham radikal terorisme kepada para mahasiswa UIN Semarang pada 28 Juli 2016 dan IAIN Surakarta pada 29 Juli 2016. Selain itu, Muthi'ah juga aktif mengikuti FGD Strategi Pencegahan Dini dalam Menangkal Paham Radikal Terorisme pada 5 s.d 7 Oktober 2016, 18 s.d 19 Oktober 2016, dan 21 s.d 22 Oktober 2016 (Wawancara dengan Muthi'ah, 23/2/2018). Tidak hanya Muthi'ah, pengurus PW Muslimat NU lainnya: Muta'allimah dan Masriah, juga terlibat aktif dalam Seminar Kebangsaan "Aktualisasi Peran Perempuan dalam Membangun Perdamaian dan Wawasan Kebangsaan” pada 16 Oktober 2016 (Wawancara dengan Masri’ah, 23/2/2018).

Sepanjang 2017, setidaknya ada 4 (empat) kegiatan yang menunjukkan adanya upaya PW Muslimat NU dalam membangun perdamaian dan harmonisasi intern dan antar umat beragama, yaitu dengan melakukan FGD dan Nota Kesepahaman antara PWNU beserta Badan Otonomnya (termasuk di antaranya PW Muslimat NU) dengan Kepolisian Daerah Jawa Tengah pada 10 Mei 2017 dalam rangka mencegah radikalisme dan terorisme di Jawa Tengah; Pada 24 Mei 2017 bekerjasama dengan Pemerintah Prop. Jawa Tengah dalam kegiatan Seminar Peran Masjid dalam Penanggulangan 
Radikalisme, Terorisme, dan Intoleran; Pada 26 s.d 27 Juli 2017 berpartisipasi dalam Pelatihan bagi Perempuan Penggerak Perdamaian (Mothers for Peace); Pada 26 Oktober 2017 berpartisiapsi dalam Rembug Kebangsaan Perempuan Pelopor Perdamaian. Sedangkan selama dua bulan pertama dari tahun 2018, PW Muslimat NU Jawa Tengah juga telah mengambil peran dalam upaya membangun perdamaian dengan melibatkan para pengurusnya secara aktif dalam kegiatan Halaqah Perempuan untuk Perdamaian pada 2831 Januari 2018 yang diselenggarakan Muslimat NU bekerjasama dengan UN Women dan Wahid Foundation, dan kegiatan FGD Merajut Kebangsaan Membendung Terorisme yang diinisiasi Kepolisian Daerah Jawa Tengah pada 6 Februari 2018 (Laporan Kegiatan Tahunan PW Muslimat NU Jawa Tengah, 2017-2018).

Keterlibatan aktif para pengurus PW Muslimat NU Jawa Tengah dalam berbagai kegiatan di atasmenunjukkan bahwa organisasi ini berperan penting dalam pembangunan perdamaian dan menciptakan kerukunan umat beragama serta mencari penyelesaian-penyelesaian praktis dari berbagai problematika sosial-aktual yang dihadapi masyarakat. Atau dengan meminjam istilah Muhammad Ja'far dalam Mun'im A. Sirry (2003: 201), maka dapat dikatakan pembangunan perdamaian yang dilakukan PW Muslimat NU Jawa Tengah adalah dengan menggunakan model dialogue in community (dialog dalam masyarakat) dan dialogue of life (dialog dalam kehidupan). model dialog ini dipandang efektif dalam menyelesaikan problem kebangsaan, seperti problem kemiskinan, kenakalan remaja, dan kriminalitas, serta membangun sikap saling mengerti, mempercayai, dan menghormati di antara mereka. Model dialog agama sediharapkan berkontribusi positif bagi perkembangan hubungan antar umat beragama di Indonesia.

PW Muslimat NU Jawa Tengah selalu menyerukan kepada para pengurus dan anggota untuk mengedepankan sikap moderatisme (tawasuth) dalam berinteraksi dengan siapapun (Wawancara dengan Ismawati, 25/2/2018). Sikap harus diupayakan dan dilestarikan. Ini disebabkan tidak seluruh pemeluk agama menerimanya sebagai sikap yang benar dari ajaran agamanya dan godaan radikalisme yang membawa intoleransi juga belum sepenuhnya hilang dari bumi Nusantara. Masih ada sebagian masyarakat 
yang berpandangan bahwa orang yang tidak seagama, sekeyakinan bahkan semazhab tidak boleh ada di negeri ini. Seandainya diperkenankan untuk tinggal, maka tidak boleh menjalankan ibadat sesuai dengan ajaran agama yang dianutnya, tidak boleh merayakan hari-hari besar keagamaannya dan seterusnya. Bahkan secara ekstrim mereka ingin memaksakan apa yang diyakininya sebagai aturan 'agama yang benar' kepada seluruh penduduk, tanpa menyadari bahwa negara menjamin kebebasan seluruh penduduk untuk memeluk agama dan beribadah sesuai dengan agama dan keyakinannya (UUD 1945 Pasal 28 \& 29; Machasin, 2017: 3).

Jika dicermati, pilihan PW Muslimat NU Jawa Tengah untuk mengedepankan moderasiberagama sejalan dengan spirit QS. Al-Baqarah: 143 yang menyatakan bahwa umat terbaik adalah umat yang moderat (ummatan wasathan), yang berada pada posisi tengah di antara dua ekstrem. Menurut Muhammad az-Zuhaili dalam bukunya al-I'tidalfiat-Tadyin: Fikran wa Sulukan wa Manhajan sebagaimana dikutip Harahap (2011: 161-162), moderat merupakan satu-satunya sikap beragama yang sesuai dengan fitrah manusia dikarenakan tiga faktor: Pertama, faktor adanya perintah untuk memuliakan manusia dalam ajaran setiap agama. Kedua, adanya kesadaran bahwa setiap agama meyakini adanya Tuhan dan utusan-Nya yang mengajarkan kebaikan. Ketiga, fakta adanya pluralisme dan multikulturalisme dalam kehidupan dan kebangsaan. Bahkan, sikap beragama yang moderat ini pula sikap yang sebenarnya dianjurkan Nabi Saw. dalam sabdanya, "Sesungguhnya agama itu mudah, dan orang-orang yang menganggap agama itu sebagai beban akan kembali pada dirinya sendiri. Maka bersikaplah moderat dan jangan terlalu ekstrim, berilah kabar gembira dan minta tolonglah kalian dengan ibadah di pagi hari dan sore hari dan juga ketika tengah malam." (HR. Al-Bukhari).

Sikap moderat, toleran, saling menghormati dan menghargai intern dan antar umat beragama perlu terus dikembangkan. Karena dengan semangat toleransi ini memungkinkan terpeliharanya perdamaian, memungkinkan terciptanya kerukunan seluruh bangsa dan warna kulit, menanamkan semangat persaudaraan dan kasih sayang di antara semua manusia, membersihkan suasana kehidupan dari berbagai moral buruk, seperti iri hati dan dengki, saling menghancurkan antara golongan yang satu dengan 
golongan yang lain, atau saling membinasakan antara ras yang satu dengan ras yang lain. Selain itu, semangat toleransi memungkinkan tercegahnya berbagai macam peperangan dan pembantaian yang ditimbulkan oleh hal-hal tersebut (Qutub, 1987: 135).

Dua peran yang dimainkan PWMuslimat NU Jawa Tengah diatas sejalan dengan Khittah Nahdliyyah yang digariskan oleh Organisasi Induknya, yakni PP Muslimat Nahdlatul Ulama, bahwa paham Ahlussunnah wa al-Jama'ah (ASWAJA) memiliki tiga karakter, yaitu: Tawasuth atau sikap moderat dalam seluruh aspek kehidupan, i'tidal atau bersikap tegak lurus dan selalu condong pada kebenaran dan keadilan, dan tawazun atau sikap keseimbangan dan penuh pertimbangan (Dikutip dari Mulyati, 2016: 107). Ketiga karakter ini dimaksudkan untuk menghindari ekstrimisme dan radikalisme sebagai sikap keberagamaan yang berkembang di Indonesia.

Meskipun peran PW Muslimat NU Jawa Tengah cukup signifikan dalam pembangunan perdamaian, namun seakan peran ini terabaikan. Stigma bahwa organisasi massa perempuan seperti PW Muslimat NU Jawa Tengahhanyalah menangani urusan domestik kaum perempuan masih mendominasi cara pandang masyarakat, yang berpangkal pada ideologi dan kultur patriarkhi. Perempuan masih dipandang sebagai obyek pembangunan, bukan subyek pembangunan. Padahal sepanjang sejarah Islam tidak pernah mempersoalkan partisipasi aktif kaum perempuan dalam pembangunan peradaban. Tidak sedikit pula pahlawan perempuan Indonesia yang terlibat dalam perjuangan kemerdekaan. Hasil survey Wahid Foundation tentang Tren Toleransi di Kalangan Perempuan di Indonesia (28/1/2018) menunjukkan bahwa perempuan Indonesia secara individu cenderung melibatkan diri dalam organisasi massa perempuan yang damai dan jauh dari konflik. Ini dikarenakan-berdasarkan survey tersebut-kaum perempuan memiliki 4 (empat) kecenderungan yaitu: (1) menyukai kebebasan dalam menjalankan ajaran agama/kepercayaan dibanding laki-laki, (2) Perempuan lebih tidak bersedia radikal dibanding laki-laki. (3) Perempuan memiliki lebih sedikit kelompok yang tidak disukai dibanding laki-laki. (4) Perempuan yang intoleran lebih sedikit dibanding laki-laki. Kecenderungan ini menjadi potensi bagi organisasi massa perempuan seperti Muslimat NU untuk 
menggerakkan dan memberdayakan tiap-tiap individu perempuan dalam pembangunan perdamaian dan perwujudan toleransi intern dan antar umat beragama.

Klasifikasi peran yang bias gender berdasar cara pandang masyarakat di atas harus segera diluruskan melalui penguatan pengarusutamaan gender dan pemberdayaan perempuan. Jika tidak, maka klasifikasi peran ini akan membentuk penandaan atau stereotipe negatif terhadap organisasi massa perempuan-dalam hal ini PW Muslimat NU Jawa Tengah-yang berakibat pada penafian peran dan eksistensinya di ruang publik, termasuk dalam upaya pembangunan perdamaian yang sejatinya harus dilakukan, baik oleh perempuan maupun laki-laki.

\section{Simpulan}

Pembangunan perdamaian menuntut sebuah transformasi nilai-nilai masyarakat secara keseluruhan yang menjamin adanya kondisi perdamaian dan keadilan, serta tegaknya martabat manusia. Untuk mencapainya perlu ditumbuhkan aspek-aspek pembangunan perdamaian secara lebih luas seperti mengembangkan sikap saling menghargai, menerima perbedaan dan mendorong perubahan arah yang lebih positif dalam bidang sosial, politik, ekonomi, dan lainnya. Upaya pembangunan perdamaian masih tetap diperlukan, karena Jawa Tengah belum terbebas sepenuhnya dari sikap diskriminatif, kekerasan, dan intoleransi yang sering kali menjadi rintangan terwujudnya perdamaian.

Peran PW Muslimat NU Jawa Tengah dalam membangun perdamaian dapat dibedakan menjadi dua bentuk: Pertama, capacity building di lingkungan anggota dan pengurusPW Muslimat NU Jawa Tengah. Banyaknya lembaga pendidikan dan maraknya majlis ta'lim yang dibina dan memiliki basis massa akar rumput yang banyak telah memperkuat posisi strategis PW Muslimat NU Jawa Tengah dalam memberikan layanan pengabdian yang bersifat religius-sosial dan memperkuat pemahaman Islam yang moderat dan toleran. Kedua, membangun harmonisasi intern dan antar umat beragama dengan bersinergi melakukan kesepakatan bersama lembaga pemerintah dan organisasi keagamaan lainnya dalam rangka menghindarkan klaim 
kebenaran dan mengembangkan toleransi. Selain itu, PW Muslimat NU Jawa Tengah juga aktif mengirimkan delegasi dalam berbagai kegiatan dalam upaya membendung terorisme dan radikalisme. Sikap moderasi beragama yang dikedepankan PW Muslimat NU Jawa Tengah sesuai dengan Khittah Nahdliyyah yang memiliki tiga karakter, yaitu: Tawasuth, i'tidal, dan tawazun.

\section{DAFTAR PUSTAKA}

Arivia, Gadis (ed.), 2007, Women for Peace: Perempuan untuk Perdamaian Indonesia, Jakarta: UI Press.

Baba, Sidek, 2002, “Toleransi dan Perbedaan Etnik dan Agama dalam Perspektif Sejarah dan Qur'ani” dalam Arsyad, Azhar. Islam \& Perdamaian Global. Yogyakarta: Madyan Press.

Fakih, Mansour, 1996, Analisis Gender \& Transformasi Sosial. Yogyakarta: Pustaka Pelajar.

Foudation, Wahid, 2018, Laporan Survei Nasional Tren Toleransi SosialKeagamaandi Kalangan Perempuan Muslim Indonesia. Jakarta: Wahid Foundation.

Hanafi, Hassan, 2002, Persiapan Masyarakat Dunia untuk Hidup secara Damai” dalam Arsyad, Azhar, Islam \& Perdamaian Global. Yogyakarta: Madyan Press.

Harahap, Syahrin, 2011,Teologi Kerukunan. Jakarta: Prenada Media.

Khariroh, Riri, 2011,"Merajut yang Terkoyak: Seputar Perempuan dan Pembangunan Perdamaian",dalam Swara Rahima, No. 35, Th. XI, Juli 2011.

Ahmad, Ibn Hanbal.1987. Musnad. Beirut: Dar al-Fikr.

Al-Bukhari, Muhammad ibn Bardizbah. 2000. Al-Jami' ash-Shahih. Kairo: Dar al-Hadis.

Machasin, "Tantangan dan Peluang Ulama Perempuan dalam Menebarkan Islam Moderat di Indonesia”. Paper dipresentasikan dalam Kongres Ulama Perempuan Indonesia (KUPI), Ponpes Kebon Jambu Cirebon, 
25-27 April 2017.

Muhammad, Husein, 2011. "Islam dan Perdamaian”,dalam Swara Rahima, No. 35, Th. XI, Juli 2011.

Mulyati, Sri, dkk. 2016. 70 Tahun Muslimat NU: Kiprah \& Karya Perempuan NU. Jakarta: T.Pn.

Pasha, Abdurrahman Azzam, 1985, Konsepsi Perdamaian Islam. Jakarta: Karya Unipress.

Qutb, Sayyid, 1987, Islam dan Perdamaian Dunia. Jakarta: Pustaka Firdaus.

Shihab, Quraish, 1998, Wawasan al-Qur'an: Tafsir Maudhu'i atas Pelbagai Persoalan Umat. Bandung: Mizan.

Sirry, Mun'im A, 2003, Membendung Militansi Agama: Iman dan Politik dalam Masyarakat Modern. Jakarta: Erlangga.

Taufiq, Imam, 2016, Al-Qur'an Bukan Kitab Teror: Membangun Perdamaian Berbasis al-Qur'an. Yogyakarta: Bentang Pustaka.

Winarno, Budi, 2003, Komparasi Organisasi Pedesaan dalam Pembangunan: Indonesia vis-a-vis Taiwan, Thailand dan Filipina. Jakarta: Media Pressindo.

Pimpinan Pusat Muslimat NU. 2006. Himpunan Keputusan Kongres XV. Jakarta: T.Pn.

Pimpinan Wilayah Muslimat NU Jawa Tengah, 2016. LaporanKegiatan PW Muslimat NU Jawa Tengah Tahun 2016.Semarang: T.Pn.

.2017, Laporan Kegiatan PW Muslimat NU Jawa Tengah Tahun. Semarang: T.Pn.

, 2018. LaporanKegiatan PW Muslimat NU Jawa Tengah Tahun 2018.Semarang: T.Pn.

Media Massa Cetak \& Elektronik:

Solo Pos, 1/1/2018, 13 Warga Jateng Ditangkap Densus 88.Diakses $15 / 2 / 2018$.

Solo Pos, 21/11/2018, 30.128 Perempuan di Jateng Nikah di Bawah Umur. Diakses 15/2/2018. 
Tribun Jateng, 7/12/2017, Ratusan Kasus Kekerasan terhadap Perempuan terjadi di Jateng Tahun 2017.Diakses 15/2/2018.

https://detiknews.com, 2/2/2018, 2 Terduga Teroris di Jateng terkait Teror Thamrin dan Filipina.Diakses 15/2/2018.

https://news.okezone.com, 21/7/2017, Perceraian di Jawa Tengah Semester I 2017 Capai 1.626 Kasus.Diakses 15/2/2018.

https://jateng.bps.go.id, 2/1/2018. 